\title{
General trends and competitiveness of Australian life insurance industry
}

\author{
Mykhailo Arych \\ Department of Finance, National University of Food Technologies, \\ Ukraine \\ mykhailo.arych@gmail.com
}

\section{Walter Darcy}

Consultant, Commonwealth bank of Australia, Australia

walter.dary@,cba.com.au

Abstract. This paper considers financial and economic indicators of Australian life insurance industry. The analysis shows the main characteristics of the current life insurance market in Australia and its factors (determinants) that will guide the life insurance market in the future. The authors have defined and calculated the main indicators of competitiveness for Australian life insurance industry (growth rates of the life insurers number'; density of insurance; penetration rates; concentration ratios; Herfindahl-Hirschman index; integrated assessment of competitiveness). In this paper, we analyzed the general trends and competitiveness of Australian life insurance market for the 1997-2017 period. The results of the Herfindahl-Hirschman index calculations, based on the net policy revenue, demonstrate that Australian life insurance industry competition is high and there is a slight concentration at this market. Herfindahl-Hirschman index for other indicators shows that competition within life insurance industry is defined as weak and underdeveloped. In addition, the analysis shows that for Australian life insurance market there are statistically significant and directly proportional impacts of, firstly, population on life insurance premiums; secondly, the number of life insurers on life insurance penetration rate via gross written premium; thirdly, the number of life insurance companies on life insurance penetration rate via assets of life insurers; and, lastly, life insurance companies' assets on gross written life insurance premiums.

Keywords: life insurance, competitiveness, density, penetration, concentration ratios, Herfindahl-Hirschman index, market structure, Australia.

JEL Classification: G22, L41 


\section{INTRODUCTION}

At present, Australian life insurance industry is a significant part of the country's financial services sector. Insurance premium, investment, and employment are the main determinants of insurance contributing to economic growth. For the insurance sector competition is very important because it stimulates the insurance market efficiency, quality of insurance products and innovations. Australian life insurance market competitiveness assessment matters for the whole financial sector in Australia.

The purpose of this paper is to analyze and to estimate the general trends and competitiveness of Australian life insurance industry. Thus, the main aims of the paper are as follow: i) defining the most effective research methodology for insurance market competitiveness assessment; ii) describing the historical and current Australian life insurance industry trends and peculiarities; analyzing the impact of life and non-life insurance market on economic growth; iii) calculation and estimation of the rates of change in life insurers' number and gross written life insurance premiums; iv) empirical investigation into the competitiveness of Australian life insurance industry by defining the indicators of insurance density, penetration, concentration ratios, Herfindahl-Hirschman index and other rates; v) testing the hypotheses for estimation the relationships between economic, demographic and life insurance market indicators.

The empirical results indicate that for Australian life insurance industry the average arithmetic of the total premium for the years 1997-2017 was 43.3 billion AUD. Additionally, the average arithmetic of the density of insurance premiums for the same research period was 2010.52 AUD. These indicators were increasing during the 1997-2017 study period. However, the values of life insurance penetration rates via gross written premium and via assets still continued to decrease from 1997 to the end of 2017. Thus, the average arithmetic deviations during 1997-2017 were as follows: via insurance premiums $-2.3 \%$, and via assets $-3.9 \%$.

The results of insurance market competitiveness assessment using Herfindahl-Hirschman index (based on the net policy revenue and share capital) have confirmed that Australian life insurance industry competition is high and there is an insignificant concentration of industry with a positive trend of improving competitiveness. The values of Herfindahl-Hirschman index based on the total revenue shows medium competition level, and the concentration of the insurance industry is medium too.

The novelty of this research can be argued according to the study results, especially in relation to Australian life insurance industry general trends and competitiveness assessment. This is not the first time this research methodology approach is used insurance market comprehensive analysis but, to the best of our knowledge, this is the most comprehensive and justified investigation of Australian life insurance market for a significant study period of 1997-2017. Also, to the best of our knowledge, the research results provide the most up-to-date insurance market competitiveness estimation.

The research paper is organized as follows. The first section outlines the literature review and the world experience in assessment methods for competitiveness and efficiency of the insurance industry. Section 2 shows the research methodology and the indicators for competitiveness and efficiency assessment. The next part presents the analysis of the trends and peculiarities of Australian life insurance industry in the context of its current and historical development conditions. Section 4 provides the theoretical estimation of the impact of insurance on economic growth. Section 5 describes the empirical results of analyzing the number of insurance companies, the total life insurance premiums, insurance density, insurance penetration, concentration ratios, Herfindahl-Hirschman index. Lastly, the final section summarizes the core findings, theoretical empirical results and suggests directions for future research.

Hence, the research study provides a comprehensive analysis of the methodological approaches to competitiveness assessment of the insurance market; the main trends and peculiarities of Australian life insurance industry (history, current dynamics, future factors and trends); theoretical explanation of the impact of insurance on economic growth; calculations of the indicators of insurance market competitiveness (density, penetration, concentration ratios, Herfindahl-Hirschman index, etc.). 


\section{LITERATURE REVIEW}

The competition at the financial sector matters for several reasons: the production efficiency of financial services; the quality of financial products; degree of innovation in the sector; the access of firms and households to financial services (Belas et al., 2014; Nguyen \& Rozsa, 2019; Nguyen et al., 2019) and a lot of other reasons. That is why the scientific research about the competition in relation to life insurance market and financial market as a whole, are the research subject for many scholars all over the world.

Bikker \& Popescu (2014) to measure competition applied a novel approach that estimates of the impact of marginal costs as indicator of inefficiency on either market shares or profits. They firstly estimated efficiency through scale economies, as an indirect measure of competition, and then proceed to compute a performance-conduct-structure indicator as a direct measure of competition.

The group of scientists Bikker \& van Leuvensteijn (2008) distinguish between various types of efficiency, particularly scale efficiency and X-efficiency. Besides, another indirect measure of competition is the so-called Boone indicator (measures the extent to which efficiency differences between firms are translated into performance differences). Bikker (2012) interpreted the existence of unused scale economies as a lack of competitive pressure to push down costs and measured competition directly using the PCS (Performance-Conduct-Structure) indicator. In addition, according to the research paper "A new way to measure competition" by Boone (2008), the price cost margin (PCM) is widely used as a measure of competition. There are a number of theoretical papers where more intense competition leads to higher PCM. The author has developed a new measure of competition, relative profit differences (RPD), which has two properties. First, RPD has a robust theoretical foundation as a measure of competition. Second, the data requirements to estimate RPD are the same as the requirements to estimate PCM.

In addition, Todorov (2016) has made a research about the competition assessments of the insurance industry is used a Panzar-Rosse approach. According to this method, the information about the insurers' competitive behavior presents via the sum of the estimated factor price elasticity, which constitute the socalled H-statistic. In addition, research findings suggest that the analyzed insurance market is far from being perfectly competitive and may require further actions to promote its competitive development.

Significant scientific results about assessment of the competition and efficiency in the insurance market were obtained by Alhassan \& Biekpe (2016). The scientists examined the empirical effect of competition on cost and profit efficiency in the insurance market in a three-stage analysis. According to the research methodology, the authors first employed the stochastic frontier analysis (SFA) to estimate cost and profit efficiency scores. In the next stage, the authors measured insurance market competition using the Panzar-Rosse (P-R) H-statistics. At last, the authors estimated a fixed-effects panel regression model to examine the effect of competition on the estimated efficiency scores.

Exploring competition in the insurance industry in Australia by Gulumser et al. (2001) applied different methods, instruments, and indicators, for instance, entry and exit barriers; company assets and their distribution; the Herfindahl-Hirschman Index (HHI) to analyze the market structure; return on assets and company size; the Rosse-Panzar H-statistic etc. Similar scientific methodology for insurance market competitive assessment used by Kasman \&Turgutlu (2007). The authors have investigated the evolution of market structure in the insurance industry using the Panzar and Rosse methodology. In addition, for test competition authors applied the four-firm concentration ratio (CR) and the HerfindahlHirschman Index (HHI) as derived from total assets.

Also group of scientists, Marović et al. (2013), suggest that the degree of competition in the insurance markets can be measured in different ways:

i) using absolute number of companies at the market;

ii) using relative participation of several leading companies (often 3 to 5); 
iii) using the Herfindahl-Hirschman index (HHI): Herfindahl-Hirschman Index measures market concentration degree via the market share of each insurance company, so this index considers all companies and not only the leading insurers.

According to Claessens (2019), there are three approaches for measuring competition:

i) the first empirical approach considers factors such as financial system concentration, the number of banks, or Herfindahl-Hirschman index;

ii) the second considers regulatory indicators to gauge the degree of contestability;

iii) the third set uses formal competition measures (H-statistics).

The modern methods for analyzing the efficiency of insurers are described by Mandić et al. (2017) in their research paper "Analysis of the efficiency of insurance companies in Serbia using the fuzzy AHP and TOPSIS methods". The scientists have proposed a fuzzy multi-criteria model that will facilitate the assessment of insurance companies' efficiency. Fuzzy Analytic Hierarchy Process and Technique for Order Performance by Similarity to Ideal Solution (TOPSIS) were used for building the proposed model.

An efficient game of competition for insurance markets with an adverse selection has constructed by Dosis (2017). In the game, each company offers two menus of contracts: a public menu and a private menu. The author showed that this simple game reduces the set of profitable deviations to the extent that a pure-strategy equilibrium exists in every market with adverse selection.

Also, it is important to analyze the impact of mutual firms on competition in the insurance market. In addition, Keneley \& Verhoef (2011) suggest that in Australia demutualization assisted market adjustment and allowed the emerging trends in the development of financial services markets to proceed. Although a period of instability followed the demutualization process the end result has been to facilitate the emergence of large wealth management institutions. The life insurance companies have historically fallen into three categories: mutual associations, publicly listed companies and government agencies (Keneley \& Keneley, 2012; Huang, Chang, \& Sia, 2019).

In addition, Fagart et al. (2002) distinguished two actors in the insurance market: mutual firms (which belong to their pooled members) and traditional companies (which belong to their shareholders). Authors suggest that the optimal contract offered via a mutual firm involves a systematic ex-post adjustment: negative or positive. In an oligopoly game, the scientists showed that three types of configurations are possible at equilibrium: either one mutual firm or insurance company is active, or a mixed structure emerges in which two or more companies share the market with or without a mutual firm.

Significant scientific results are presented by Simionescu (2019) and the author was constructed a panel autoregressive-model (PVAR) for analyzing the insurance market. This research result has suggested that the "indemnities paid by the insurance companies negatively affected the liquidity but with a lag of two periods after changes in indemnities".

Furthermore, Grmanová \& Strunz (2017) studying the efficiency of insurers was conducted on the application of DEA and Tobit analyses. This research determined the relationship between technical efficiency and profitability (ROA, ROE and the size of assets) of insurers. As a result, "the relationship between the technical efficiency score in the CCR and BCC models and all the groups formed on the basis of the return on assets and the group formed basing on the return on equity was not confirmed". Analogous results were obtained in the further research continued by Grmanová \& Pukala (2018).

Malyovanyi et al. (2018) and Nesterchuk et al. (2018) has significant study results on Ukrainian insurance market research. In general, Malyovanyi et al. (2018) conducted a study about the influence of social expenditures and their structure on economic growth in the OECD countries for the years 19802015. Results from the research show that higher rates of economic growth are observed in the countries with the accumulative principle of financing of social expenditures, and a low level of profitability of investment activity was the main reason for the slow development of the system of non-state social insurance in Ukraine. Additionally, Nesterchuk et al. (2018) investigated features of the present tendencies 
of the functioning of the Ukrainian agrarian insurance system and prospects for future development. The authors defined a set of strategic principles for the insurance market.

Thus, there isn't the one unique methodology and that's why it requires more and more research studies for defining advantages and disadvantages of its instruments.

\section{METHODOLOGY}

The source of the statistical data for the study was the information materials received from Australian Prudential Regulation Authority (next - APRA): information materials of Australian life insurance industry; and, from Australian Bureau of Statistics (next - ABS): information materials of the demographic statistics in Australia.

General trend and a competitiveness analysis of Australian life insurance industry was completed according to the research methodology as follows:

1. Assessment of the rates of change in life insurers' number $(\delta)$ in Australia according to the formula (1) (Shirinyan, 2014):

$$
\delta=100 \%\left[\mathrm{~N}_{2}-\mathrm{N}_{1}\right] / \mathrm{N}_{1} \text {, }
$$

where, $\mathrm{N}_{2}-$ number of insurers at the end of the research period, $\mathrm{N}_{1}-$ number of insurers at the beginning of the research period. This indicator is used to indirectly assess barriers to entry into the insurance market, time-dependent, and is characterized as the rate of increase/decrease of the number of insurers over a period (Shirinyan, 2014).

2. Assessment of the density of insurance $(\alpha, \beta)$, which is calculated as follows (Rakshit, 2017; Kaur, 2015):

$$
\begin{aligned}
& \alpha=I P / N_{\text {pop }}, \\
& \beta=N_{\text {pop }} / N,
\end{aligned}
$$

where, $\alpha$ - density of insurance premiums (average insurance premium per capita), $\beta$ - density of insurance companies (number of people per life insurer), $I P$ - total insurance premiums, $N_{\text {pop }}-$ population, $N$ - the whole number of life insurers.

With the increasing density of insurance premiums, it will be shown that the insurance market is developing positively and the amount of insurance premiums is increasing stable (Kaur, 2015). Furthermore, the increasing density of insurance companies will characterize the decrease of competition in the insurance market, and on the contrary, its decrease - the increase of competition.

3. Assessment of the penetration rates $\left(\eta_{\mathrm{IP}}, \eta_{\mathrm{A}}\right)$, which are calculated as follows (Shirinyan, 2014; Rakshit, 2017; Das \& Shome, 2016; Chizoba et al., 2018):

$$
\begin{aligned}
& \eta_{\mathrm{IP}}=100 \% \mathrm{IP} / \mathrm{GDP}, \\
& \eta_{\mathrm{A}} \square=100 \% \mathrm{~A} / \mathrm{GDP},
\end{aligned}
$$

where, $\eta_{I P} \square-$ insurance penetration via total premiums, $\eta_{A} \square-$ insurance penetration via assets, $\mathrm{A}-$ total assets of life insurance, GDP - gross domestic product. Insurance penetration is measured as a percentage of total insurance premium collected to the GDP of the country (Rakshit, 2017). Also, the insurance penetration rate indicates how much the insurance sector contributes to the national economy and provides a good numerical basis for international comparison across regions (Das \& Shome, 2016; Kaur, 2015).

4. Assessment of the concentration ratios $\left(C R_{1}, C R_{3}, C R_{4}, C R_{10}\right)$ which are calculated, for example, for $C R_{4}$ as follows (Kasman \& Turgutlu, 2007; Marović et al., 2013; Jaloudi \& Bakir, 2019; Dimic et al., 2018; Skuflic et al., 2011):

$$
\begin{aligned}
& C R_{4}=K_{1}+K_{2}+K_{3}+K_{4}, \\
& K_{i}=\frac{I P_{i}}{I P_{\text {total }}},
\end{aligned}
$$


where $\mathrm{i}$ - ranges from 1 to $\mathrm{m}, \mathrm{m}$ - the whole number of insurers, $K_{i}$ - the industry share of an insurance company via total insurance premium, $I P_{i}$ - insurance premiums via i-number of an insurance company, $I P_{\text {total }}$ - the total amount of insurance premium of the insurance industry (Novozhilova, 2012; Sukpaiboonwat et al., 2014; Sharku \& Shehu, 2016; Lotti, 2017).

These concentration indicators (rates) are commonly used to estimate market monopolization, as the share of the largest insurance companies at the market is determined. For example, in Ukraine the market is considered a monopoly if the share of one insurance company exceeds $35.0 \%$, three $-50.0 \%$, four or five $-70.0 \%$ (Shirinyan, 2014). Additionally, the concentration rate is most often determined using a number of companies in a particular sector. And also, it is usually defined as the percentage of the total supply in a sector (Kasman \& Turgutlu, 2007; Kramaric \& Kitic, 2012; Maksimović \& Kostic, 2012).

5. Assessment of the Herfindahl-Hirschman index $(H H I)$ which are calculated as follows (Kasman \& Turgutlu, 2007; Marović et al., 2013; Claessens, 2009; Jaloudi \& Bakir, 2019; Dimic et al., 2018; Kubiszewska, 2017):

$$
H H I=\sum_{\mathrm{i}=1}^{\mathrm{N}} \mathrm{K}_{\mathrm{i}}^{2}
$$

The level of competitiveness using HHI can be measured according to the conditions required as follows (Novozhilova, 2012; Sukpaiboonwat et al., 2014; Sharku \& Shehu, 2016; Lotti, 2017):

i) a high competition level $(H H I \leq 1000)$, the concentration is insignificant;

ii) a medium competition level $(1000 \leq H H I \leq 1800)$, the concentration is medium too;

iii) a low competition level $(1800 \leq H H I \leq 10000)$, the concentration of the insurance industry is significant (Kramaric \& Kitic, 2012; Maksimović \& Kostic, 2012; Scanlon et al., 2007; Shirinyan, 2014).

However, the main disadvantage of this indicator is that it is the most suitable for competitiveness assessment of large enterprises (Alhassan \& Biekpe, 2016; Gulumser et al., 2001).

6. Integrated assessment of competitiveness (IA) which is calculated taking into account the nature of the concentration ratios and the Herfindahl-Hirschman index as follows (Shirinyan, 2014):

$$
I A=\sqrt{C R_{4} \times H H I} .
$$

Integrated assessment of competitiveness rate $(I A)$ can be measured according to the conditions required as follows (Shirinyan, 2014):

i) $0<I A \leq 30$, where competitiveness is the highest and optimal;

ii) $30<I A \leq 180$ - competitiveness is high;

iii) $180<I A \leq 350$ - market competitiveness and monopolization are low;

iv) $350<I A \leq 650$ - competitiveness is weak and meets the conditions of monopoly competition;

v) $650<I A \leq 1000-$ market competitiveness is minimal.

\section{LIFE INSURANCE INDUSTRY: TRENDS AND PECULIARITIES}

The life insurance industry is a significant part of the financial services sector in Australia. In addition, there are sections of the life insurance industry that can do better in delivering the protection they promise whilst remaining financially viable long into the future (Life Insurance Industry, 2018). The first life insurance companies in Australia were branches of British companies in the 1830s. The establishment of an Australian life insurance industry as such took place in the 1870s (Keneley, 2005). Nowadays the life insurance market in Australia covers a range of insurance products including life cover; total and permanent disability (TPD) cover; trauma cover ("critical illness" or "recovery" insurance); and income protection (Life Insurance Industry, 2018; Griffin, 2017).

The life insurance industry in Australia is unique amongst global markets because of its dominance of risk products over savings products. Almost all life insurance companies reported a profit for their financial year-end in the 12 months to December 2017 (Life Insurance Insights Report, 2018). 
And according to Griffin (2017), Australian life insurance companies are used many different market strategies that are as follows: high focus on the contestable market; focus on distribution partners and finding new distribution opportunities; smaller sub-scale Direct offers; abandoning contestable markets; focus on selling directly to existing customer base; unwinding bank and wealth business integration? banks are progressively exiting life insurance manufacturing; typically single channel niche players, etc.

In addition, Keneley (2004) investigates of strategies adopted for Australian life insurers as they moved into the increasingly competitive environment triggered using the lifting of government restrictions on banking practices. The author suggests that there is a link between changing information costs and changing organizational structures. The foundations regulatory control of Australian life insurance industry has been based on the two main periods of legislative intervention by Keneley (2005): i) the 1870s, when Australian colonies enacted separate pieces of legislation to cover life insurers within their jurisdiction; ii) In 1945, when Commonwealth government assumed the regulatory mantle given to it under Section 51 (XIV) of the constitution.

In general, the responsibility for the regulation of Australian life insurance industry is divided between ASIC (Australian Securities and Investments Commission) and APRA (Australian Prudential Regulation Authority) as follows: i) ASIC - licensing, conduct, product operation, product disclosure and marketing; and ii) APRA - registration, prudential standards, and data collection.

The life insurance industry is one of the powerful tools for social and economic welfare. There are a lot of factors (determinants) that will guide the insurance sector's future course (demographic changes, policy decisions, macro-economic variables, technological innovations). According to the life insurance industry specifics distinguish growth enablers (emerging customers; ageing population; reduced role of the state; start of secular bear bonds market) and potential impediments (low-interest rates; continued regulatory oversight; competition from alternative products; structural growth) (Crawford et al., 2017).

Besides these factors, Sandhu \& Ward (2017) distinguish current (happening now) and future (over the next 10 years) trends in the life insurance:

1. Happening now: Changing customer expectations (Desire for interfaces; Rapid search and easy price comparison); New Technology (Mobile and apps; Big data analytics; Peer-to-peer platforms); Tighter regulation (Stricter conduct rules; Tightening of capital); New competition (Alternative capital providers; InsurTech start-ups; OEMs/telcos).

2. In the future: Changing customer expectations (Suitable offerings; Frictionless experience; Integrated financial management); New Technology (Artificial Intelligence; IoT; Genetics); Tighter regulation (Customer ownership of data; Open customer access for product providers); New competition (Online retailers; Infotech giants).

In addition, it is possible to highlight a number of emerging trends that will impact on Australian insurance industry in both the short and long term: Insurtech, Digital, Blockchain, Artificial intelligence, Cyber insurance, Data analytics, Customer focus, Risk mitigation, New accounting standard IFRS 17, Conduct and mis-selling (General Insurance Industry Review, 2017).

In accordance with EY Global insurance trends analysis (2013), there are few main factors affecting the insurance industry: macroeconomic conditions; competitive pressures; natural catastrophe insured losses; reinsurance pricing and capacity; technology; regulatory reforms; mergers and acquisitions (Crawford et al., 2017). In Australian insurance market, the main competition issues are divided into two groups as follows (Competition of Australian private health insurance market, 2013):

group 1: issues related to the behavior of market participants (growth in intermediaries; potential lack of competition along the supply chain; vertical integration; the complexity of products.

group 2: issues related to the operation of the regulatory framework (barriers to entry; ensuring portability is efficient; alternative methods for implementing risk equalization and to improve fairness across insurers; regulation around pricing; alignment of risk equalization; impact on community rating). 


\section{THE IMPACT OF INSURANCE ON ECONOMIC GROWTH}

Life insurance is one of the main financial institutions that mobilizes fund for investment for the wellbeing of an economy (Fashagba, 2018) and long-term stability of aging developed societies (Bielawska, 2019; Thalassinos et al., 2019). In addition, the role of the insurance sector and links into other financial sectors have grown in importance (Haiss \& Sümegi, 2006). Insurance as a financial intermediary plays a significant role in the economic growth of any country (Skare \& Porada-Rochoń, (2019a, 2019b). Many researchers have dealt with the relationship between insurance and economic growth (Pant \& Bahadur, 2017).

A lot of papers analyze the relationship between economic growth and written premiums, penetration and density. Ul Din et al. (2017) has argued that for developed countries there is a significant relationship between life insurance, net written premiums and density. In addition, Iyodo et al. (2018) showed that non-life insurance penetration had a positive and substantial effect on economic growth. Furthermore, Olayungbo \& Akinlo (2016) have found a positive relationship between insurance penetration and economic growth for Egypt, while short-run negative and long-run positive effects for Kenya, Mauritius, and South Africa. And negative effects - for Algeria, Nigeria, Tunisia, and Zimbabwe. Additionally, Lee et al. (2018) also have argued that the relationship between economic growth and insurance is varied in different countries due to different initial income levels, locations. Thus, the effects are very complicated. In general, Cristeaa et al. (2014) have established that there is a high correlation between insurance penetration, density and economic growth, measured using GDP per capita.

The role of insurance can be investigated in several ways: economical role, financial role, psychological role, educational role and social role (Ungur, 2017). Insurance premiums, investment and employment are the main determinants of insurance contributing to economic growth (Pant \& Bahadur, 2017).

According to Pradhan et al. (2017), Nwani \& Omankhanlen (2019), Satrovic (2019) it is really need continue to study the relationship between the insurance market and economic growth. Thus, the life premium was positively insignificant to economic growth and the non-life premium - negatively, while the insurance investment - positively (Nwani \& Omankhanlen, 2019). In addition, Pradhan et al. (2017) using the vector auto-regression model and the Granger causality test has shown that in the long run, developments in the insurance industry have had a significant impact on the economic growth, and in the short term, the inter-relationships differ by countries in different stages of development.

The influence of the insurance industry on the macroeconomic activity can be analyzed from two viewpoints: i) in providing indemnification; ii) its role as an institutional investor (Outreville, 2011).

Applying the Autoregressive Distributed Lag (ARDL) approach for studying the effects of life and non-life insurance on economic growth, Olayungbo (2015) stated that long and short-run dynamics confirms the positive contribution of life and non-life insurance on economic growth.

Therefore, there are a lot of positive effects and benefits of life insurance for the economic growth that following below (Stojaković \& Jeremić, 2016; Sawadogo et al., 2018; Petrova, 2019; Satrovic, 2019):

i) enhances the financial stability of families and businesses;

ii) facilitates competitiveness and development of trade and commerce;

iii) substitutes and complements public sector expenditures on security programs;

iv) increases liquidity, availability of total capital stock in an economy and efficiency of capital allocation (Njegomir \& Stojić, 2010);

v) insurers and reinsurers have economic incentives to help insurers to reduce losses (Petrova, 2014);

vi) encouraging the accumulation of new capital and fostering a more efficient allocation (Outreville, 2011; Hu, Su, \& Lee, 2013);

vii) benefiting risk identification, reinforcement, and repairing;

viii) strengthening financial management of enterprises; 
ix) enhancing the risk management of individuals;

x) improving credit for the entire society (Hui \& Xin, 2017; Hussein \& Alam, 2019; Ramoutar, 2019).

Besides, Simionescu et al. (2017) studying the determinants of economic growth in the Czech Republic, Slovak Republic, Hungary, Poland and Romania have noted that that the FDI promoted economic growth in all countries, except the Slovak Republic. This research is limited by the consideration of a relatively small set of data for analysis. Additionally, Ying et al. (2017) and Wang \& Li (2019) study of the insurance contribution for economic growth in China and have augured that there is a significant interacting relationship between life, non-life insurance, and economic growth. It is found that the development of China's foreign capital insurance market has not promoted China's economic growth (Wang \& Li, 2019).

\section{EMPIRICAL RESULTS}

\subsection{The number of insurance companies}

Our empirical analysis starts with a presentation of the dynamics of changes in life insurers' number. Therefore, the rate of change in insurers' number $(\boldsymbol{\delta})$ was calculated for the years 1997-2017 in two ways: 1) the rate of change for each one year; 2) the rate of change for every five years. The results of the calculations are presented in Table 1.

Table 1

The growth rate in life insurers' number in Australia

\begin{tabular}{|c|c|c|c|c|c|}
\hline \multirow{2}{*}{ Year } & \multirow{2}{*}{$\begin{array}{c}\text { Insurers' } \\
\text { number }\end{array}$} & \multicolumn{4}{|c|}{ Rates of change in life insurers' number } \\
\cline { 3 - 6 } & 48 & $1997-2001$ & -12.5 & $1997-1998$ & -6.3 \\
\hline 1997 & 45 & $1998-2002$ & -11.1 & $1998-1999$ & -2.2 \\
\hline 1998 & 44 & $1999-2003$ & -11.4 & $1999-2000$ & -4.5 \\
\hline 1999 & 42 & $2000-2004$ & -11.9 & $2000-2001$ & 0.0 \\
\hline 2000 & 42 & $2001-2005$ & -11.9 & $2001-2002$ & -4.8 \\
\hline 2001 & 40 & $2002-2006$ & $-12,5$ & $2002-2003$ & -2.5 \\
\hline 2002 & 39 & $2003-2007$ & -17.9 & $2003-2004$ & -5.1 \\
\hline 2003 & 37 & $2004-2008$ & -29.7 & $2004-2005$ & 0.0 \\
\hline 2004 & 37 & $2005-2009$ & -29.7 & $2005-2006$ & -5.4 \\
\hline 2005 & 35 & $2006-2010$ & -25.7 & $2006-2007$ & -8.6 \\
\hline 2006 & 32 & $2007-2011$ & -3.1 & $2007-2008$ & -18.8 \\
\hline 2007 & 26 & $2008-2012$ & 7.7 & $2008-2009$ & 0.0 \\
\hline 2008 & 26 & $2009-2013$ & 7.7 & $2009-2010$ & 0.0 \\
\hline 2009 & 26 & $2010-2014$ & 7.7 & $2010-2011$ & 19.2 \\
\hline 2010 & 31 & $2011-2015$ & -9.7 & $2011-2012$ & -9.7 \\
\hline 2011 & 28 & $2012-2016$ & 3.6 & $2012-2013$ & 0.0 \\
\hline 2012 & 28 & $2013-2017$ & 3.6 & $2013-2014$ & 0.0 \\
\hline 2013 & 28 & & & $2014-2015$ & 0.0 \\
\hline 2014 & 28 & & & $2015-2016$ & 3,6 \\
\hline 2015 & 29 & & & & 0,0 \\
\hline 2016 & 29 & & & & \\
\hline 2017 & & & & & \\
\hline
\end{tabular}

Source: Authors' results according to the data of APRA.

According to Table 1, the number of insurance companies during 1997-2017 constantly decreasing for 19 insurance companies or 39.6 \%: from 48 insurers in 1997, to 29 - in 2017. Furthermore, the minimum number of life insurance companies equal to 26 , which was in the three time periods such as 2008, 2009, 2010; maximum - 48 insurers in 1997. In addition, the biggest decreasing the number of life 
insurance companies in Australia was during 2007-2008: -18.8\%; the biggest increase - in 2010-2011: 19.2\%. Also, during 1997-2017 there were eight stable time periods: 2000-2001, 2004-2005, 2008-2009, 2009-2010, 2012-2013, 2013-2014, 2016-2017 where the rates of change in life insurers' number were equal $0,0 \%$. Also, it should be noted that exactly during the last years the rates of change in life insurers number in Australia were the most permanent. Altogether, comparing the rates of change in life insurers' number $(\delta, \%)$ for a five-year time period it was determined that the biggest decreasing the number of Australian life insurers was during2004-2008, 2005-2009, where $\delta=-29.7 \%$.

\subsection{Total insurance premiums}

Total insurance premium is a major indicator of the efficiency of each insurance company. The total premium shows the sum of both direct premiums written and assumed premiums written before the effect of ceded reinsurance. Research results about the total insurance premium of Australian life insurance market are presented in Graph 1.

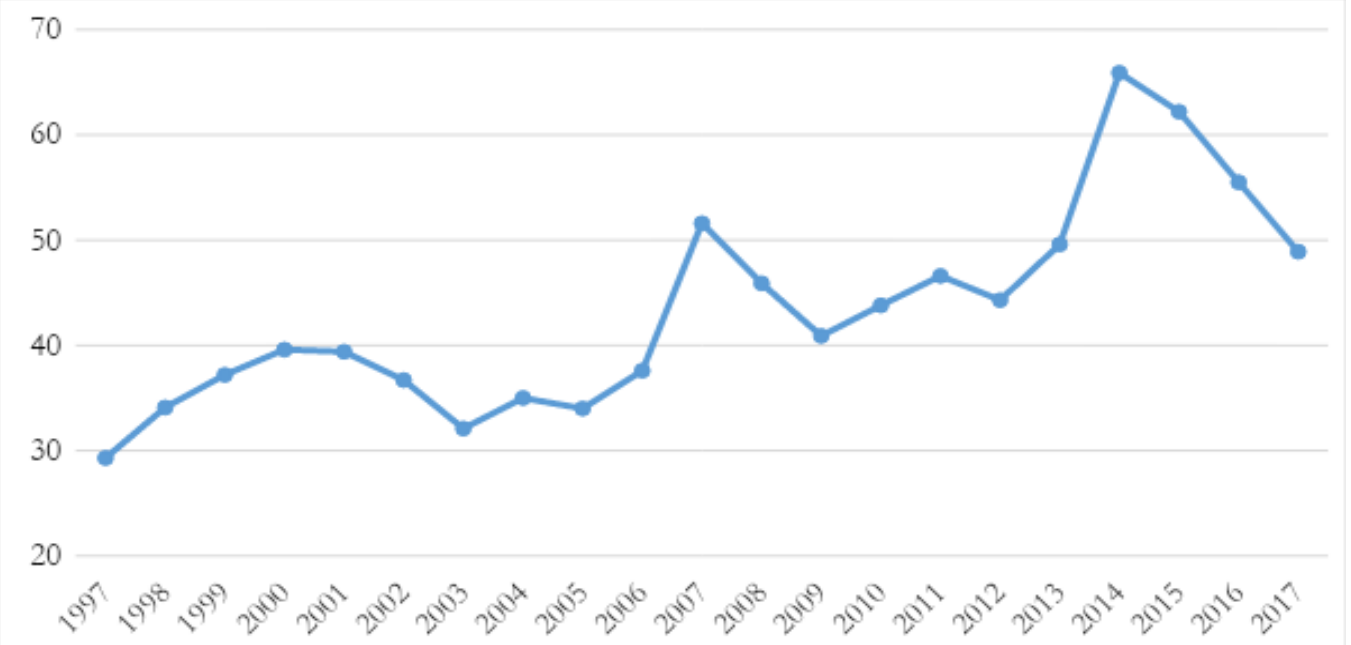

Graph 1. Total insurance premium of Australian life insurance industry, 1997-2017, billon AUD* Source: Authors' results according to the data of APRA.

In general, the total insurance premium dynamics of Australian life insurance industry increases during the research period from 29.3 billion AUD in 1997, to 48.9 billion AUD in 2017, so deviation equal to 19.6 billion AUD or $40.1 \%$. Besides, Graph 1 describes the cyclical change in the amount of insurance premiums collected via Australian life insurance companies. In addition, it is important to consider the critical values of calculated indicators:

- The minimum of the total premium: 29.3 billion AUD (1997);

- The maximum of the total premium: 65.9 billion AUD (2014);

- The average arithmetic of the total premium for 1997-2017: 43.3 billion AUD;

- The minimum deviation: -6.7 billion AUD (2015-2016) and -12.5\% (2002-2003);

- The maximum deviation: 16.3 billion AUD (2013-2014) and $32.9 \%$ (2013-2014);

- The average arithmetic deviation for the 1997-2017: $3.5 \%$.

\subsection{Insurance density}

The next part of competitiveness for Australian life insurance shows the insurance density calculations': density of insurance premiums $(\alpha)$ and the density of insurance companies $(\beta)$. The density 
of insurance premiums $(\alpha)$, which is calculated according to the formula (2), displays the average insurance premium per capita (Graph 2).

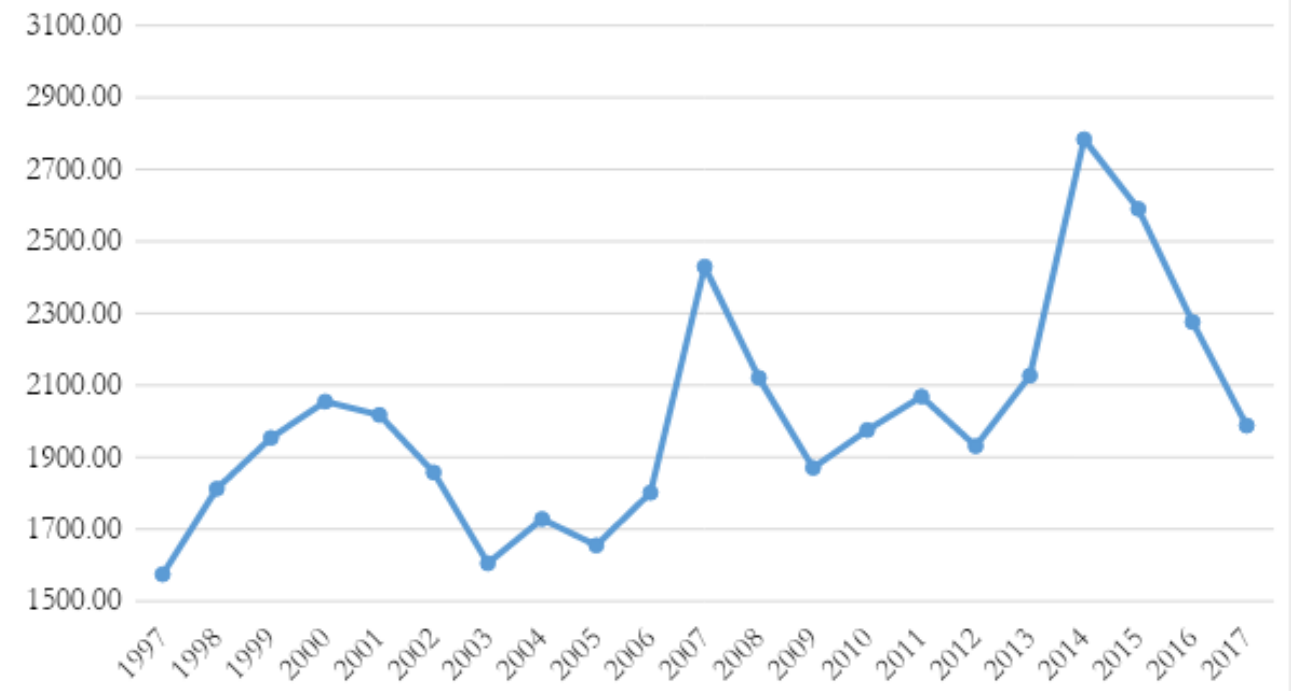

\section{Graph 2. Density of insurance premiums (the average insurance premium per capita) in Australia, AUD*}

Source: Authors' results according to the data of APRA.

Looking at Graph 2 figures, we notice that during the 1997-2017 research period it was the cyclical change the insurance density indicator calculated via insurance premiums. Graph 2 shows that the main statistics critical values were as follows:

- The minimum of the density of insurance premiums: 1574.50 AUD (1997);

- The maximum of the density of insurance premiums: 2783.81 AUD (2014);

- The average arithmetic of the $\alpha$ for the years 1997-2017: 2010.52 AUD;

- The minimum deviation: -314.35 AUD (2015-2016) and -15.60 \% (2015-2016);

- The maximum deviation: 657.04 AUD (2013-2014) and 32.64 \% (2013-2014);

- The average arithmetic deviation for the years 1997-2017:1.0\%.

Furthermore, the Graph 1 and Graph 2 indicate that dynamics of total insurance premiums (Graph 1) and density of insurance premiums (Graph 2) have the same trends and can be distinguished as follows:

- three stages of a significant increase of the indicators: from 1997 to 2000; from 2005 to 2007; from 2012 to 2014);

- three stages of a significant decrease of the indicators: from 2000 to 2003; from 2007 to 2009; from 2014 to 2017;

- two stages of insignificant decrease of the indicators: from 2004 to 2005 and from 2011 to 2012;

- two stages of an insignificant increase of the indicators: from 2003 to 2004 and from 2009 to 2011).

The density of insurance companies $(\beta)$ shows how many people per life insurers in the country. In addition, this economic indicator is important for assessment of the insurance market competitiveness. Therefore, Graph 3 displays our results of calculating the density of insurance companies in relation to Australian life insurance industry (thousands of people per life insurer) for the years 1997-2017. 


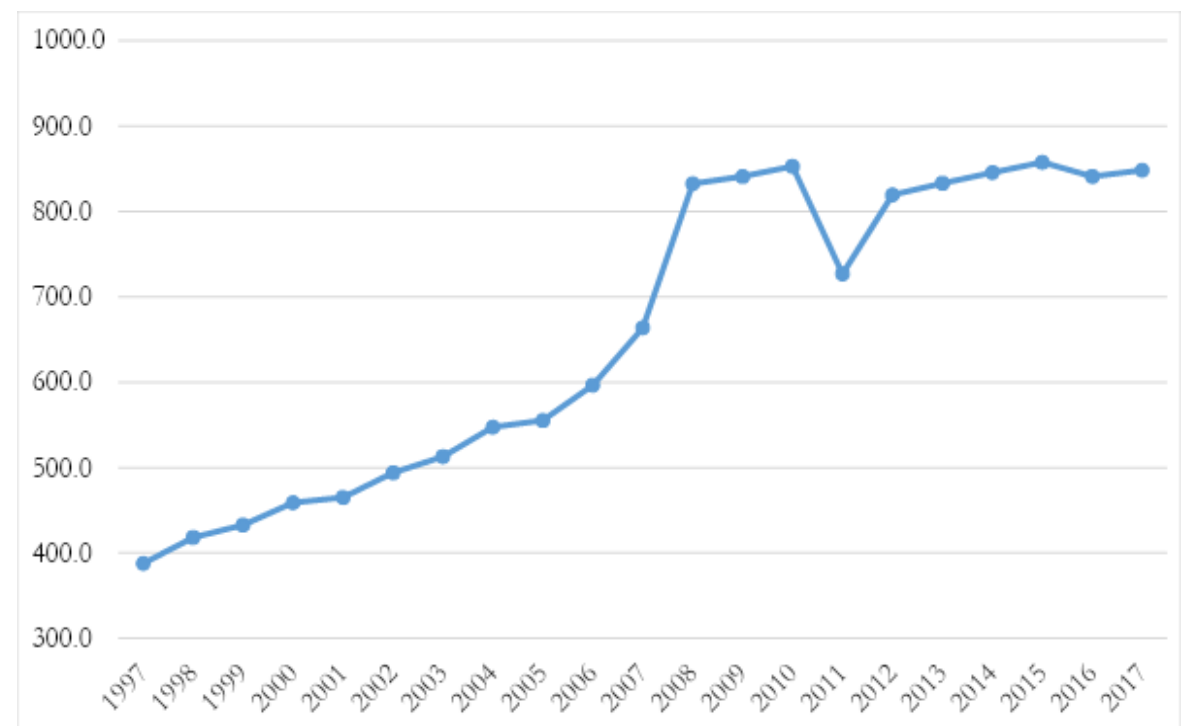

Graph 3. The density of insurance companies in relation to Australian life insurance industry (thousands of people per life insurer), 1997-2017*

Source: Authors' results according to the data of APRA and ABS.

Graph 3 shows the positive trend of the density of insurance companies in relation to Australian life insurance industry (thousands of people per life insurer) for the years 1997-2017. In detail, the main statistics critical values were as follows:

- The minimum of the density of insurance companies: 387.7 thousand of people per life insurer (1997);

- The maximum of the density of insurance companies: 857.6 thousand of people per life insurer (2015);

- The average arithmetic of the density of insurance companies for the years 1997-2017: 658.5 thousand of people per life insurer;

- The minimum deviation: -126.1 thousand of people per life insurer (2010-2011), and -14.8\% (2010-2011);

- The maximum deviation: 168.8 thousand of people per life insurer (2007-2008), and $25.4 \%$ (2007-2008);

- The average arithmetic deviation for the years 1997-2017: 4.2\%.

\subsection{Insurance penetration}

The importance of insurance services in the market is determined via the impact on the formation of gross domestic product (GDP) and can be estimated via the share of total premiums in the gross domestic product (as a percentage of GDP). This indicator is called the "insurance penetration" or just "penetration" ("penetration rate"), and we have calculated it according to the formulas (4) and (5). The insurance penetration rate indicates the level of development of the insurance sector in a country. Besides, we consider as an important part of our research to estimate the share of life insurance market assets in the GDP. Our calculating results are described in the Graph 4. 


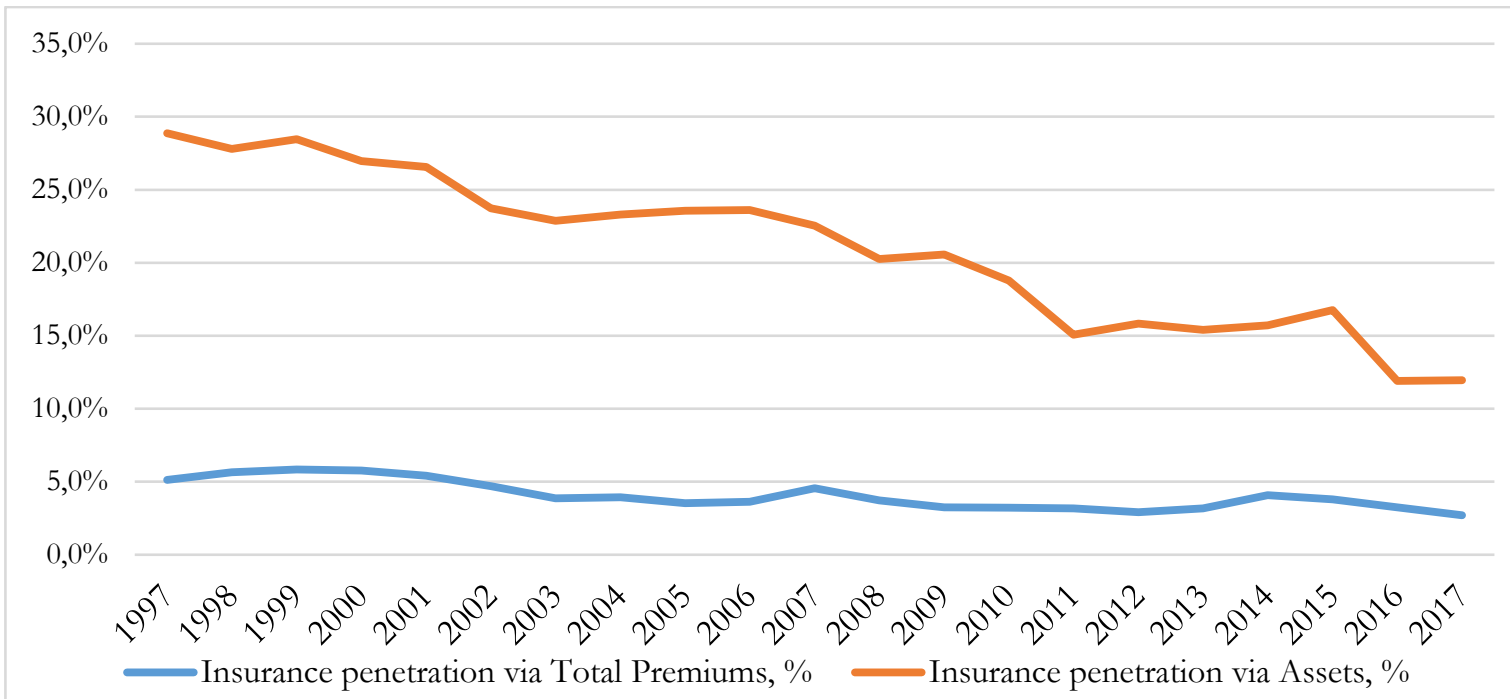

Graph 4. Australian life insurance market penetration indicators (via total premiums and via assets), 1997-2017, \%*

Source: Authors' results according to the data of APRA and ABS.

Graph 4 presents the statistical results for the years 1997-2017 and shows the negative trend of Australian life insurance market penetration indicators: via total premiums and via assets. In general, the penetration via total premiums has decreased during research period from $5.1 \%$ in 1997, to $2.7 \%$ in 2017 , so deviation equal to $2.4 \%$. In addition, the penetration via assets has decreased too from $28.9 \%$ in 1997 , to $12.0 \%$ in 2017 , so deviation equal to $16.9 \%$.

In detail, the main statistics critical values were as follows:

1) Insurance penetration via total premium:

- The minimum of the insurance penetration via total premium: $2.7 \%$ (2017);

- The maximum of the insurance penetration via total premium: $5.8 \%$ (1999, 2000);

- The average arithmetic of the insurance penetration via total premium for 1997-2017: 4.1 \%;

- The minimum deviation: $-0.9 \%$ (2007-2008), and -19.6\% (2007-2008);

- The maximum deviation: $1.0 \%$ (2006-2007), and 28.1\% (2013-2014);

- The average arithmetic deviation for the years 1997-2017: -2.3\%.

2) Insurance penetration via assets:

- The minimum of the insurance penetration via assets: $11.9 \%$ (2016);

- The maximum of the insurance penetration via assets: $28.9 \%$ (1997);

- The average arithmetic of the insurance penetration via assets for the years 1997-2017: 21.0\%;

- The minimum deviation: $-4.9 \%$ (2015-2016), and -29.2\% (2015-2016);

- The maximum deviation: $1.1 \%$ (2014-2015), and 7.0 \% (2014-2015);

- The average arithmetic deviation for the years 1997-2017: -3.9\%.

\subsection{Concentration ratios}

Assessment of the competitiveness of life insurance industry based on the concentration indicator was calculated according to the formulas (6) and (7). The financial and economic indicators that, in our opinion, characterize the success and effectiveness of life insurance companies are total premiums and total assets. These figures also characterize the share of the insurance company on the insurance industry and are presented in Table 2. 
The concentration ratios of Australian life insurance industry

\begin{tabular}{|c|c|c|c|c|c|c|}
\hline \multirow{3}{*}{ Year } & \multicolumn{6}{|c|}{ Industry share, $\%$} \\
\hline & \multicolumn{3}{|c|}{ via "total premiums" } & \multicolumn{3}{|c|}{ via "total assets" } \\
\hline & $C R_{1}$ & $C R_{3}$ & $C R_{10}$ & $C R_{1}$ & $C R_{3}$ & $C R_{10}$ \\
\hline 1998 & 26.0 & 44.0 & 83.0 & 27.0 & 51.0 & 83.0 \\
\hline 1999 & 26.0 & 45.0 & 83.0 & 30.0 & 53.0 & 86.0 \\
\hline 2000 & 25.0 & 53.0 & 88.0 & 28.0 & 59.0 & 91.0 \\
\hline 2001 & 25.0 & 56.0 & 89.0 & 29.0 & 60.0 & 91.0 \\
\hline 2002 & 22.0 & 53.0 & 91.0 & 28.0 & 59.0 & 93.0 \\
\hline 2003 & 23.0 & 55.0 & 91.0 & 28.0 & 59.0 & 93.0 \\
\hline 2004 & 25.0 & 58.0 & 90.0 & 28.0 & 59.0 & 93.0 \\
\hline 2005 & 29.0 & 64.0 & 91.0 & 29.0 & 61.0 & 93.0 \\
\hline 2006 & 30.0 & 67.0 & 92.0 & 30.0 & 63.0 & 93.0 \\
\hline 2007 & 28.0 & 72.0 & 95.0 & 30.0 & 65.0 & 95.0 \\
\hline 2011 & 20.0 & 50.0 & - & - & - & - \\
\hline 2012 & 24.0 & 57.0 & - & - & - & - \\
\hline 2013 & 25.0 & 58.0 & - & - & - & - \\
\hline 2014 & 24.0 & 62.0 & - & - & - & - \\
\hline 2015 & 25.8 & 56.8 & 86.5 & 30.5 & 70.0 & 93.2 \\
\hline 2016 & 25.5 & 54.6 & 87.3 & 40.7 & 65.4 & 90.7 \\
\hline 2017 & 23.0 & 49.3 & 85.3 & 40.2 & 65.6 & 90.6 \\
\hline
\end{tabular}

Source: Authors' results according to the data of APRA.

Table 2 shows the results of the concentration ratios $\left(C R_{1}, C R_{3}, C R_{10}\right)$ that calculated via total premiums and via total assets of Australian life insurance industry. The results indicate of the different dynamic trends of increasing and decreasing the concentration ratios $C R_{1}, C R_{3}, C R_{10}$ at the insurance market. However, we are faced with the limitation of information and resources about Australian life insurance market structure. Therefore, we could not calculate some concentration ratios in Table 2.

The external effects, that insurance companies provide for society, are related to the amount of taxes paid by insurance companies and can be described as the net income of the country. The internal effect or result is "net profit/loss after tax" because it is the amount of money that the insurance company receives as a reward or additional over the result of the activity (Table 3).

Table 3

The concentration ratio $C R_{i}$ is based on the "net profit/loss after tax", "tax" of Australian life insurance industry for the years 2015-2017

\begin{tabular}{|c|c|c|c|c|c|c|c|c|}
\hline \multirow{2}{*}{ Year } & \multicolumn{8}{c|}{ Life insurance industry, \% } \\
\cline { 2 - 8 } & $C R_{1}$ & $C R_{3}$ & $C R_{4}$ & $C R_{5}$ & $C R_{10}$ & $C R_{15}$ & $C R_{20}$ \\
\hline \multicolumn{7}{|c|}{ "net profit/loss after tax" } \\
\hline 2015 & 23.0 & 44.4 & 54.6 & 62.5 & 89.7 & 97.3 & 99.9 \\
\hline 2016 & 13.1 & 37.4 & 47.6 & 55.7 & 86.8 & 97.3 & 99.8 \\
\hline 2017 & 17.5 & 42.3 & 52.7 & 61.5 & 90.5 & 97.7 & 99.8 \\
\hline \multicolumn{7}{|c|}{ "tax" } \\
\hline 2015 & 32.0 & 57.6 & 66.3 & 74.3 & 93.0 & 98.1 & 99.7 \\
\hline 2016 & 25.8 & 53.5 & 61.7 & 69.7 & 91.6 & 97.7 & 99.6 \\
\hline 2017 & 24.9 & 51.7 & 60.9 & 68.2 & 92.0 & 97.7 & 99.4 \\
\hline
\end{tabular}

Source: Authors' results according to the data of APRA.

Table 3 suggests that the share of taxes paid by biggest insurance companies in life insurance industry tends to decline during the study period of 2015-2017. The tendency of changing share via "net profit/loss after tax" is not so straightforward, because for a different number of companies are characterized using a multidirectional change in the indicators of concentration ratio. 


\subsection{Herfindahl-Hirschman index}

The outcome of competitiveness assessment of Australian life insurance industry was the HerfindahlHirschman index calculations and an integrated assessment of competitiveness (Table 4).

Table 4

General indicators of competitiveness of Australian life insurance industry

\begin{tabular}{|c|c|c|c|c|}
\hline \multirow{3}{*}{ Year } & $\begin{array}{c}\text { Competitiveness } \\
\text { indicators }\end{array}$ & \multicolumn{2}{|c|}{ Indicators, that used for assessment of competitiveness } \\
\cline { 2 - 5 } & Total revenue & $\begin{array}{c}\text { Net policy } \\
\text { revenue }\end{array}$ & Total assets \\
\hline \multirow{4}{*}{2015} & $H H I$ & 0.13490 & 0.06907 & 0.18944 \\
\cline { 2 - 5 } & $H H I^{*} 10000$ & 1349.0 & 690.8 & 1894.4 \\
\cline { 2 - 5 } & $C R_{4}, \%$ & 63.2 & 39.0 & 35.0 \\
\hline \multirow{4}{*}{2016} & $I A$ & 292.0 & 164.1 & 0.21407 \\
\cline { 2 - 5 } & $H H I$ & 0,12643 & 679.9 & 71.4 \\
\cline { 2 - 5 } & $H H I^{*} 10000$ & 1264.4 & 38.7 & 391.0 \\
\hline \multirow{3}{*}{2017} & $C R_{4}, \%$ & 61.8 & 162.1 & 0.21065 \\
\cline { 2 - 5 } & $I A$ & 279.5 & 6.06629 & 71.5 \\
\cline { 2 - 5 } & $H H I$ & 0.11011 & 37.5 & 388.1 \\
\hline
\end{tabular}

Source: Authors' results according to the data of APRA.

The level of competitiveness of Australian life insurance industry meets all three possible levels of competitiveness (high, medium, low) depending on the values of the calculated Herfindahl-Hirschman index. The Table 6 indicates that the Herfindahl-Hirschman index calculated via "net policy revenue" demonstrates high competition level, and the concentration of the insurance industry is insignificant (HHI $\leq 1000)$. Dynamics of changes for these indicators during the 2015-2017 characterizes the positive trend of improving (increasing) of the competitiveness. The Herfindahl-Hirschman indexes are calculated via "total revenue" characterize medium competition level, and the concentration of the insurance industry is medium too $(1000 \leq H H I \leq 1800)$. Dynamics of changes for these indicators for the years 2015-2017 also show a positive trend of improving (increasing) of the competitiveness. The HerfindahlHirschman index that is calculated via "total assets" characterizes low competition level, and the concentration of the insurance industry is significant $(1800 \leq H H I \leq 10000)$.

\subsection{Test of hypotheses}

Taking into account the research results according with Table 1 (presented the growth rate in life insurers' number in Australia), Table 3 (concentration ratios); and Graph 1 (described the total insurance premium of Australian life insurance industry), Graph 2 (average insurance premium per capita in Australia) and Graph 3 (thousands of people per life insurer), Graph 4 (life insurance market penetration indicators via total premiums and via assets) we consider it necessary to investigate of some scientific hypotheses that describe the relationship between these economic indicators. These calculations based on the correlation-regression analysis as follows: defining the one-factor regression model $(\mathrm{Y}=\mathrm{A}+\mathrm{BX}$, where $\mathrm{Y}$ - dependent variable, $\mathrm{X}$ - independent variable; A and B - regression coefficients), Pearson correlation coefficient $(\mathrm{r})$, determination coefficient $\left(\mathrm{r}^{2}\right)$, Student's t-criterion $\left(\mathrm{t}_{\mathrm{st}}\right)$, critical value of the Student's $\mathrm{t}$ criterion for a given degrees of freedom $\left(t_{c r}\right)$, average approximation error $(E)$, statistical level of indicators dependence (D, significant or insignificant) and P-value. The value of the regression coefficients was calculated based on the sample data.

Thus, for the insurance market competitiveness assessment and for checking of the relationships between demographic statistics and insurance market indicators we put forward and justified a null and 
alternative hypotheses. A null hypothesis (when regression coefficients are equal to zero) is suggested for estimation of statistical significance of the regression coefficient. Thus, for the coefficient $\beta_{i}$, the formulas for the null hypothesis $(\mathrm{H} 0)$ and the alternative hypothesis: $\mathrm{H} 0: \beta_{i}=0-$ the coefficient is insignificant (a null hypothesis states there is no statistically significant correlation between any indicators); and H1: $\beta_{i} \neq$ 0 - the coefficient is significant (an alternative hypothesis shows that correlation dependence exists) (Malyovanyi, Nepochatenko, \& Nesterchuk, 2018). For all our research hypotheses, we also test the null hypothesis; and the alternative hypothesis is each of the hypotheses that we study (H2-H12). These hypotheses are presented and described in Table 5.

Also, it is necessary to check if these coefficients are statistically significant. Consequently, the probability that $\mathrm{H} 0$ hypothesis is true for the corresponding coefficient describes via P-value (when Pvalue is less than $5.0 \%$ - the coefficient is statistically significant (reliability $=95 \%$ ), and that's why can be included in the model; and when P-value is greater than 5.0\% - the coefficient is statistically insignificant with a reliability of 95\% (Malyovanyi, Nepochatenko \& Nesterchuk, 2018).

In addition, it is important to analyze the difference between Student's t-criterion $\left(\mathrm{t}_{\mathrm{st}}\right)$ and critical value of the Student's t-criterion for a given degrees of freedom ( $\left.t_{\mathrm{cr}}\right)$. If $\mathrm{t}_{\mathrm{st}}>\mathrm{t}_{\mathrm{cr}}$, then level of indicators dependence is statistically significant, and when $t_{\mathrm{St}}<\mathrm{t}_{\mathrm{cr}}-$ statistically insignificant. The next and the last step for correlation-regression analysis is related to define the average approximation error, which allows us to estimate the adequacy of the regression model. Hence, if average approximation error $(\mathrm{E})$ is less than $7,0 \%$, then such adequacy is high; if $\mathrm{E}$ no more than 15,0\% - adequacy is acceptable. All other values of the average approximation error (E) show that the adequacy of the regression model is low. Thus, let's move on to a correlation analysis of hypotheses (Table 5).

Table 5

The characteristics of the research hypotheses

\begin{tabular}{|c|c|c|c|c|c|c|}
\hline \multicolumn{5}{|c|}{ Description of the alternative hypotheses H2-H12 } & \multicolumn{2}{|c|}{ Correlation results } \\
\hline \multirow{3}{*}{ Marking } & \multicolumn{2}{|c|}{ Variables } & \multirow{3}{*}{$\begin{array}{c}\text { Nature of the } \\
\text { influence of } \\
\text { X on Y }\end{array}$} & \multirow{3}{*}{$\begin{array}{c}\text { Analysis } \\
\text { period } \\
\text { (set of data) }\end{array}$} & \multirow{3}{*}{$\mathbf{r}$} & \multirow{3}{*}{$\mathbf{r}^{2}$} \\
\hline & independent & dependent & & & & \\
\hline & $\mathbf{X}$ & $\mathbf{Y}$ & & & & \\
\hline $\mathrm{H} 2$ & \multirow{2}{*}{ Population } & $\begin{array}{l}\text { Insurance } \\
\text { premiums }\end{array}$ & $\begin{array}{c}\text { Directly } \\
\text { proportional }\end{array}$ & \multirow{6}{*}{$\begin{array}{c}21 \text { years } \\
(1997-2017)\end{array}$} & 0.829 & 0.687 \\
\hline $\mathrm{H} 3$ & & $\begin{array}{c}\text { Life insurers' } \\
\text { number }\end{array}$ & $\begin{array}{c}\text { Inversely } \\
\text { proportional }\end{array}$ & & -0.879 & 0.772 \\
\hline $\mathrm{H} 4$ & \multirow{8}{*}{$\begin{array}{l}\text { Life insurers' } \\
\text { number }\end{array}$} & $\begin{array}{l}\text { Insurance } \\
\text { premiums }\end{array}$ & $\begin{array}{c}\text { Directly } \\
\text { proportional }\end{array}$ & & -0.711 & 0.506 \\
\hline $\mathrm{H} 5$ & & Assets & $\begin{array}{c}\text { Directly } \\
\text { proportional }\end{array}$ & & -0.871 & 0.758 \\
\hline H6 & & $\begin{array}{c}\text { Penetration via } \\
\text { premiums }\end{array}$ & $\begin{array}{c}\text { Directly } \\
\text { proportional }\end{array}$ & & 0.822 & 0.676 \\
\hline $\mathrm{H} 7$ & & $\begin{array}{c}\text { Penetration via } \\
\text { assets }\end{array}$ & $\begin{array}{c}\text { Directly } \\
\text { proportional }\end{array}$ & & 0.849 & 0.721 \\
\hline $\mathrm{H} 8$ & & $C R_{3}$ via premiums & $\begin{array}{c}\text { Inversely } \\
\text { proportional }\end{array}$ & $\begin{array}{c}17 \text { years } \\
(1998-2007 ; \\
2011-2017)\end{array}$ & -0.389 & 0.151 \\
\hline H9 & & $C R_{10}$ via premiums & $\begin{array}{c}\text { Inversely } \\
\text { proportional }\end{array}$ & \multirow{3}{*}{$\begin{array}{c}13 \text { years } \\
(1998-2007 ; \\
2015-2017)\end{array}$} & -0.224 & 0.050 \\
\hline H10 & & $C R_{3}$ via assets & $\begin{array}{c}\text { Inversely } \\
\text { proportional }\end{array}$ & & -0.928 & 0.860 \\
\hline H11 & & $C R_{10}$ via assets & $\begin{array}{c}\text { Inversely } \\
\text { proportional }\end{array}$ & & -0.548 & 0.300 \\
\hline H12 & Assets & $\begin{array}{l}\text { Insurance } \\
\text { premiums }\end{array}$ & $\begin{array}{c}\text { Directly } \\
\text { proportional }\end{array}$ & $\begin{array}{c}21 \text { years } \\
(1997-2017)\end{array}$ & 0.648 & 0.419 \\
\hline
\end{tabular}

Source: Authors' research results. 
Table 5 provides the description of the alternative hypotheses H2-H12 (independent $(\mathrm{X})$ and dependent $(\mathrm{Y})$ variables, interconnection nature between $\mathrm{X}$ and $\mathrm{Y}$, study period and correlation results: Pearson correlation coefficient and determination coefficient). The research results show that for four alternative hypotheses (H2, H6, H7 and H12) correlation coefficients are described the high level $(r>0,6)$ of interconnection between population and life insurance premium $(\mathrm{r}=0,829)$, number of life insurance companies and penetration rate via premiums $(\mathrm{r}=0,822)$, number of life insurance companies and penetration rate via assets $(r=0,849)$, life insurers' assets and gross written premiums $(r=0,648)$. Such positive values indicate the directly proportional interconnection between indicators for $\mathrm{H} 2, \mathrm{H} 6, \mathrm{H} 7 \mathrm{and}$ H12. Thus, according for these results the following research hypotheses can be accepted. But it requires much more correlation-regression analysis and calculations for defining, for example, the level of statistically significant of the indicator's dependence.

Furthermore, for better checking and testing null and alternative hypotheses, it is important to compare value of $t_{\mathrm{st}}$ and $\mathrm{t}_{\mathrm{cr}}$. Hence, if $\mathrm{t}_{\mathrm{st}}>\mathrm{t}_{\mathrm{cr}}-$ the null hypotheses are rejected; and, if $\mathrm{t}_{\mathrm{st}}<\mathrm{t}_{\mathrm{cr}}-$ the null hypothesis is accepted (Malyovanyi, Nepochatenko, \& Nesterchuk, 2018). The results of the correlationregression calculations are presented in Table 6.

Table 6

Regression results of the research hypotheses

\begin{tabular}{|c|l|c|c|c|c|c|}
\hline \multirow{2}{*}{$\begin{array}{l}\text { Alternative } \\
\text { hypothesis }\end{array}$} & \multirow{2}{*}{ Regression equation } & \multicolumn{5}{|c|}{ Regression indicators } \\
\cline { 3 - 7 } & & $\mathrm{t}_{\mathrm{St}}$ & $\mathrm{t}_{\mathrm{cr}}$ & $\mathrm{D}$ & P-value & $\begin{array}{c}\mathrm{E}, \\
\%\end{array}$ \\
\hline $\mathrm{H} 2$ & $\mathrm{y}=-45.84054+4,17053 \mathrm{E}-06 \mathrm{X}$ & 6.458 & 2.093 & significant & 0.000004 & 9.8 \\
\hline $\mathrm{H} 3$ & $\mathrm{y}=103.89993-3,25541 \mathrm{E}-06 \mathrm{X}$ & -8.017 & 2.093 & insignificant & 0.000000 & 8.1 \\
\hline $\mathrm{H} 4$ & $\mathrm{y}=76.45377-0.96574 \mathrm{X}$ & -4.410 & 2.093 & insignificant & 0.000338 & 11.6 \\
\hline H5 & $\mathrm{y}=359.62033-4.07657 \mathrm{X}$ & -7.714 & 2.093 & insignificant & 0.000000 & 5.3 \\
\hline H6 & $\mathrm{y}=0.16143+0.11362 \mathrm{X}$ & 6.303 & 2.093 & significant & 0.000006 & 12.2 \\
\hline H7 & $\mathrm{y}=-0.79791+0.63549 \mathrm{X}$ & 7.011 & 2.093 & significant & 0.000002 & 12.5 \\
\hline H8 & $\mathrm{y}=72.07467-0.45550 \mathrm{X}$ & -1.634 & 2.131 & insignificant & 0.124638 & 9.1 \\
\hline $\mathrm{H} 9$ & $\mathrm{y}=93.61560-0.13550 \mathrm{X}$ & -0.761 & 2.201 & insignificant & 0.464411 & 3.4 \\
\hline $\mathrm{H} 10$ & $\mathrm{y}=90.91484-0.81815 \mathrm{X}$ & -8.235 & 2.201 & insignificant & 0.000009 & 2.6 \\
\hline H11 & $\mathrm{y}=102.48732-0.30655 \mathrm{X}$ & -2.171 & 2.201 & insignificant & 0.055085 & 2.6 \\
\hline H12 & $\mathrm{y}=2.05182+0.18781 \mathrm{X}$ & 3.705 & 2.093 & significant & 0.001621 & 12.6 \\
\hline
\end{tabular}

Source: Authors' research results.

Thus, the findings reveal that there are four accepted alternative hypotheses (H2, H6, H7 and H12), and seven rejected alternative hypotheses (H3, H4, H5, H8, H9, H10, H11). Confirmation of accepted hypotheses are, firstly, the values of correlation coefficients which $r>0.6$; secondly, for these hypotheses regression results $t_{s t}>t_{c r}$, that's why the null hypothesis is rejected; thirdly, P-values are less than $5.0 \%$ level of indicators dependence is statistically significant. In addition, the average approximation error for these hypotheses are related to the acceptable adequacy of the regression models. Altogether, other alternative hypotheses $(\mathrm{H} 3, \mathrm{H} 4, \mathrm{H} 5, \mathrm{H} 8, \mathrm{H} 9, \mathrm{H} 10, \mathrm{H} 11)$ are rejected, and there are no reasons to reject the null hypothesis because of $\mathrm{t}_{\mathrm{st}}<\mathrm{t}_{\mathrm{cr}}$.

As a result of accepted and confirmed alternative hypotheses it is important to define the interpretation of $\mathrm{H} 2, \mathrm{H} 6, \mathrm{H} 7$ and $\mathrm{H} 12$ as follows:

i) according to H2: the population has statistically significant directly proportional impact on life insurance premiums;

ii) according to H6: the number of life insurance companies has statistically significant directly proportional impact on life insurance penetration rate via gross written premium;

iii) according to $\mathrm{H} 7$ : the number of life insurance companies has statistically significant directly proportional impact on life insurance penetration rate via assets of the life insurers; 
iv) according to H12: life insurance companies' assets have statistically significant directly proportional impact on gross written life insurance premiums.

Comparisons with previous studies by the world scientific community show that one of the main insurance market competition indicator is the Herfindahl-Hirschman index (Kasman \& Turgutlu, 2007; Marović et al., 2013; Claessens, 2009; Jaloudi \& Bakir, 2019; Dimic et al., 2018; Skuflic et al., 2011), which also often use by governments of different countries, and sometimes it is a compulsory tool for assessing the level of competition in the insurance market (Shirinyan, 2014). Another one of the most important rate assessments of competition is concentration rate (Kasman \& Turgutlu, 2007; Marović et al., 2013; Jaloudi \& Bakir, 2019; Dimic et al., 2018; Skuflic et al., 2011).

At present, high-quality research that describes the competition and competitiveness of Turkish (Kasman \& Turgutlu, 2007), South African (Alhassan \& Biekpe, 2016), former Yugoslavian (Marović et al., 2013), Jordan (Jaloudi \& Bakir, 2019), Croatian (Skuflic et al., 2011), Thai (Sukpaiboonwat et al., 2014), Albanian (Sharku \& Shehu, 2016), Serbian, Slovenian, Romanian, Austrian (Maksimović \& Kostic, 2012), U.S. (Scanlon et al., 2007), Ukrainian (Shirinyan, 2014), Indian (Rakshit, 2017; Kaur, 2015), Nigerian (Chizoba et al., 2018), Bulgarian (Todorov, 2016), Dutch (Bikker, 2012) and Australian (Gulumser et al., 2001) insurance market was conducted based on the different methodological approaches.

Altogether, there aren't many previous studies about competitiveness and life insurance market in Australia. The closest to our study are research results by Gulumser et al. (2001), but here the author describes the general, not life, insurance industry. However, there are many papers that present the common and historical research about Australian life and non-life insurance market (Keneley \& Verhoef, 2011; Griffin, 2017; Keneley \& Keneley, 2012; Kirwan, 2016; Keneley, 2005). That is why our scientific work and its results have a competitive edge on the scientific value of insurance research in general and the life insurance market of Australia in particular.

\section{CONCLUSIONS}

The assessment of the general trends and competitiveness of Australian life insurance industry is an important and obligatory part of the whole Australian insurance market research study. The investigated results give an opportunity to make the conclusions about the general life insurance industry trends and peculiarities, methodological approaches for the competitiveness assessment of its empirical results.

The analysis shows that the most often the researchers and scholars make assessment of insurance market competitiveness using the following methods and approaches: the Herfindahl-Hirschman Index, insurance density, insurance penetration, concentration ratios, entropy concentration index, Lorenz curve, Gini coefficient, Tideman-Hall concentration index, Rosenbluth index, Comprehensive Concentration Index, Hanna and Key Index, Haus index, Panzar-Rosse approach and H-statistic, Performance-ConductStructure indicator, price cost margin indicator, Fuzzy Analytic Hierarchy Process and Technique for Order Performance by Similarity to Ideal Solution, etc.

The density assessment of insurance premiums (average insurance premium per capita) and total insurance premiums analysis show that its indicators have the same trends of changes.

The study presents the insurance penetration rates assessment (penetration by assets and premiums). The results show the negative trends of Australian life insurance market penetration indicators: via total premiums and via assets. In general, the penetration via total premiums has decreased during research period from $5.1 \%$ in 1997 , to $2.7 \%$ in 2017 , so deviation equal to $2.4 \%$. Also, the penetration via assets has decreased too from $28.9 \%$ in 1997 , to $12.0 \%$ in 2017 , so deviation equal to $16.9 \%$.

In addition, the results of the Herfindahl-Hirschman index calculations, based on the "net policy revenue" and "share capital" argues that Australian life insurance industry competition is high and there is an insignificant of industry concentration. Dynamics of changes of these indicators during 2015-2017 characterizes a positive trend of improvement of competitiveness. The HHI calculated via "total revenue" 
suggests medium competition level, and concentration of the insurance industry is medium too. Dynamics of changes in these indicators for the years 2015-2017 also suggests a positive trend of improving competitiveness. The Herfindahl-Hirschman indexes calculated via "total assets" suggests low competition level, and concentration of the insurance industry is significant.

Our paper investigates the correlation-regression analysis for assessment the effect of impact, firstly, the population on insurance premiums and on number of life insurance companies; secondly, number of insurance companies on the total insurance premiums, assets, penetration via assets and via premiums, concentration ratios via assets and via premiums; and, at last, assets to the insurance premiums. The results indicate that there are statistically significant and directly proportional impacts of, firstly, population on life insurance premiums; secondly, life insurers' number on life insurance penetration rate via gross written premiums; thirdly, the life insurers' number on life insurance penetration rate via assets of life insurers; and, lastly, life insurance companies' assets on gross written life insurance premiums.

Altogether, our research study has some limitations. The biggest limitation is related to the data of Australian life insurance market structure: for example, market share via gross written premiums or assets of Australian life insurers for the years 2008-2014. Such circumstances are the reason of the concentration ratios calculations $\left(C R_{1}, C R_{3}, C R_{10}\right)$ via total insurance premiums and assets not for a wholestudy period of 1997-2017. Also, these limited data has made it possible to calculate the concentration ratios $\left(C R_{1}\right.$, $\left.C R_{3}, C R_{4}, C R_{5}, C R_{10}, C R_{15}, C R_{20}\right)$ via "net profit/loss after tax", "tax" and the Herfindahl-Hirschman index only for the years 2015-2017. But these small set of data we did not use for correlation-regression analysis. It should also be noted that such limits of data create restrictions for future research about the competitiveness of Australian life insurance industry,

Based on the literature review of the research results of the world scientific community, we are going to continue the analysis and study the competitiveness of Australian life insurance industry using the following methodology: entropy concentration index, Lorenz curve, Gini coefficient, Tideman-Hall concentration index, Rosenbluth index, Comprehensive Concentration Index, Hanna and Key Index, Haus index, Panzar-Rosse approach and H-statistic, Performance-Conduct-Structure indicator, price cost margin indicator, Fuzzy Analytic Hierarchy Process and Technique for Order Performance by Similarity to Ideal Solution. Applying these methods for insurance market competitiveness assessment will make possible to obtain completely new scientific results both for Australian insurance market and for all international insurance and actuarial science.

\section{REFERENCES}

Alhassan, A.L., \& Biekpe, N. (2016). Competition and efficiency in the non-life insurance market in South Africa. Journal of Economic Studies, 43(6), 882 - 909. https://doi.org/10.1108/JES-07-2015-0128

Australian Bureau of Statistics (1997-2017). Australian Demographic Statistics, Canberra, AGPS.

Australian Prudential Regulation Authority (1997-2017). Life Insurance Market Statistics, Canberra, AGPS.

Australian Prudential Regulation Authority (2015-2017). Life Insurance Institution-level Statistics, Canberra, AGPS.

Belas, J., Cipovova, E., \& Demjan, V. (2014). Current trends in area of satisfaction of bank clients in the Czech Republic and Slovakia. Tranformations in Business and Economics, 13(3): 219-234.

Bielawska, K. (2019). Economic activity of Polish pensioners in the light of quantitative research. Equilibrium. Quarterly Journal of Economics and Economic Policy, 14(1), 149-165. https://doi.org/10.24136/eq.2019.007

Bikker, J., \& Popescu, A. (2014). Efficiency and competition in the Dutch non-life insurance industry. Discussion PaperSeries, 14-12.

Bikker, J.A. (2012). Performance of the life insurance industry under pressure: efficiency, competition and consolidation, DNB Working Paper, 357, De Nederlandsche Bank, Amsterdam.

Bikker, J.A., \& van Leuvensteijn, M. (2008). Competition and efficiency in the Dutch life insurance industry. Applied Economics, 40, 2063-2084.

Boone, J. (2008). A new way to measure competition, Economic Journal, 118, 1245-126. 
Chizoba, P.E. (2018). Effect of savings rate on insurance density in Nigeria. International Journal of Advanced Academic Research. Social \& Management Sciences, 4(5), 72-87.

Chizoba, P. et al. (2018). Effect of Inflation Rate on Insurance Penetration of Nigerian Insurance Industry. International Research Journal of Finance and Economics, 170, 66-76.

Claessens, S. (2009). Competition in the Financial Sector: Overview of Competition Policies. IMF Working Paper. WP $/ 09 / 45$.

Competition in the Australian private health insurance market (2013). Premiums and Competition Unit. Research Paper 1. The Private Health Insurance Administration Council (PHIAC).

Crawford, S. et al. (2017). Global insurance trends analysis 2016. EYGM Limited.

Cristeaa et al. (2014). The relationship between insurance and economic growth in Romania compared to the main results in Europe - a theoretical and empirical analysis. Procedia Economics and Finance, 8, 226 - 235.

Das, S., \& Shome, M.K. (2016). A study on determinants of insurance penetration in the context of India. International Journal of Marketing and Human Resource Management (IJMHRM), 7(3), 85-94.

Dimic, M. et al. (2018). Measuring the Concentration of Insurance sector - the Case of Southeastern European Countries. Research Papers. Organizacija, 51, 50-64. doi: 10.2478/orga-2018-0004

Dosis, A. (2017). Efficient Competition in Insurance Markets. Available at SSRN: https://ssrn.com/abstract=2666964 or http://dx.doi.org/10.2139/ssrn.2666964

Fagart, M.C. et al. (2002). Risk Mutualization and Competition in Insurance Markets. The Geneva Risk and Insurance Review. doi: 10.1023/A:1021948826240

Fashagba, M.O. (2018). The impact of insurance on economic growth in Nigeria. Afro Asian Journal of Social Sciences, IX(I).

General Insurance Industry Review 2017. KPMG. Available at: www.kpmg.com/au/insurancereview.

Griffin, K. (2017). TAL and Australian Life Insurance Market. TAL.

Grmanová, E., \& Pukala, R. (2018). Efficiency of insurance companies in the Czech Republic and Poland. Oeconomia Copernicana, 9(1), 71-85. https://doi.org/10.24136/oc.2018.004.

Grmanová, E., \& Strunz, H. (2017). Efficiency of insurance companies: Application of DEA and Tobit analyses. Journal of International Studies, 10(3), 250-263.

Gulumser, M. et al. (2001). Competition in the general insurance industry. Available at: http://www.huebnergeneva.org/documents/InsurSymposium.pdf.

Haiss, P., \& Sümegi, K. (2006). The Relationship of Insurance and Economic Growth - A Theoretical and Empirical Analysis. Paper for presentation at the 2006 EcoMod Conference, Hongkong.

Hu, H., Su, M., \& Lee, W. (2013). Insurance activity and economic growth nexus in 31 regions of China: bootstrap panel causality test. Romanian Journal of Economic Forecasting, XVI(3).

Huang, W. S., Chang, C. T., \& Sia, W. Y. (2019). An empirical study on the consumers' willingness to insure online. Polish Journal of Management Studies, 20(1), 202-212, DOI: 10.17512/pjms.2019.20.1.18

Hui, Z., \& Xin, Z. (2017). The dynamic relationship between insurance development and economic growth: New evidence from China's coastal areas. African Journal of Business Management, 11(5), 102-109. doi:10.5897/AJBM2016.8219

Hussein, M., \& Alam, S. (2019). The Role of Insurance Sector in the Development of the Economy of Oman, Global Journal of Economics and Business, 6(2), 356- 364.

Iyodo et al. (2018). Effect of insurance industry performance on economic growth in Nigeria, Int. J. Bus. Financ. Manage. Res., 6, 22-33.

Jaloudi, M., \& Bakir, A. (2019). Market Structure, Efficiency, and Performance of Jordan Insurance Market. International Journal of Business and Economics Research, 8(1), 6-13. doi:10.11648/j.ijber.20190801.12

Kasman, A., \& Turgutlu, E. (2007). Competitive Conditions in the Turkish Non-Life Insurance Industry. Review of Middle East Economics and Finance, 4(1), 81-96. doi: 10.2202/1475-3693.1071

Kaur, J. (2015). Insurance penetration and density in India. International Journal of Business Management, 2(1), 765-770.

Keneley, M. (2004). Adaptation and change in the Australian life insurance industry: An historical perspective. Available from: https://www.researchgate.net/publication/24067192.

Keneley, M. (2005). Control of the Australian life insurance industry: an example of regulatory externalities within the Australian financial sector 1870-1945. Australian economic history review, 45(1), 1-22. 
Keneley, M.J., \& Keneley, M. (2012). Structural adjustment and change in the Australian life insurance industry post demutualization. Available from: https://www.researchgate.net/publication/228431318.

Keneley, M.J., \& Verhoef, G. (2011). The decision to demutualise: An Analysis of the Pressures for Change. The case of life insurers in Australia and South Africa. Available from: https://www.researchgate.net/publication/228620607.

Kirwan, B. (2016). Australia: Market overview 2015.

Kramaric, T.P., \& Kitic, M. (2012). Comparative analysis of concentration in insurance markets in new EU member states. International Journal of Social, Behavioral, Educational, Economic, Business and Industrial Engineering, 6(6), 13231326.

Kubiszewska, K. (2017). Banking concentration in the Baltic and Western Balkan states - selected issues. Oeconomia Copernicana, 8(1), 65-82. https://doi.org/10.24136/oc.v8i1.5.

Lee et al. (2018). Insurance Development and Economic Growth, Financial Statistical Journal, 1.

Life Insurance Industry (2018). Parliamentary Joint Committee on Corporations and Financial Services. Printed by the Senate Printing Unit, Parliament House, Canberra.

Life Insurance Insights Report 2018. KPMG.

Lotti, L. (2017). Concentration risk. Cassa depositi e prestiti (cdp).

Maksimović, L., \& Kostić, M. (2012). Limitations in the application of concentration indicators - Example of insurance market in Serbia, Croatia, Slovenia, Romania and Austria. Politika preduréca, 60, 199-205.

Malyovanyi, M., Nepochatenko, O., \& Nesterchuk, Y. (2018). Conceptual Approaches to Improving the Functioning of Non-state Social Insurance Institutions in Ukraine. Economics \& Sociology, 11(2), 289-304.

Mandić et al. (2017). Analysis of the efficiency of insurance companies in Serbia using the fuzzy AHP and TOPSIS methods, Economic Research-Ekonomska Istraživanja, 30:1, 550-565. doi: 10.1080/1331677X.2017.1305786

Marović, B. et al. (2013). Competition in insurance markets of the region of former Yugoslavia. EKONOMIKA PREDUZEĆA. Transition and Restructuring, 354-363.

Measuring insurance development: beyond the insurance penetration rate (2017). Access to insurance intiative. International Association of Insurance Supervisors. Report of the 21st A2ii - IAIS Consultation Call.

Nesterchuk, Y., Prokopchuk, O., Tsymbalyuk, Y., Rolinskyi, O., \& Bilan, Y. (2018). Current status and prospects of development of the system of agrarian insurance in Ukraine. Investment Management \& Financial Innovations, 15(3), 56.

Njegomir, V., \& Stojić, D. (2010). Does insurance promote economic growth: the evidence from ex-Yugoslavia Region. EKON. MISAO I PRAKSA DBK. GOD XIX, 1, 31-48.

Nguyen, T. A. N., Polách, J., \& Vozńáková, I. (2019). The role of financial literacy in retirement investment choice. Equilibrium. Quarterly Journal of Economics and Economic Policy, 14(4), 569-589. https://doi.org/10.24136/eq.2019.027.

Nguyen, T. A. N., \& Rozsa, Z. (2019). Financial Literacy and Financial Advice Seeking for Retirement Investment Choice. Journal of Competitiveness, 11(1), 70-83. https://doi.org/10.7441/joc.2019.01.05

Novozhilova, N. (2012). Analysis of financial ratios of insurer for risk management. Proceedings of the 12th International Conference "Reliability and Statistics in Transportation and Communication" (RelStat'12), Riga, Latvia, 250-259.

Nwani, A.T., \& Omankhanlen, A.E. (2019). Insurance Receivables and Economic Growth: The Case of Nigeria, Journal of Physics: Conference Series, 1378. doi:10.1088/1742-6596/1378/4/042093

Olayungbo, D., \& Akinlo, A. (2016). Insurance penetration and economic growth in Africa: Dynamic effects analysis using Bayesian TVP-VAR approach, Cogent Economics \& Finance, 4(1), 1-19, doi: http://dx.doi.org/10.1080/23322039.2016.1150390

Olayungbo, D.O. (2015). Effects of Life and Non-Life Insurance on Economic Growth in Nigeria: An Autoregressive Distributed Lag (ARDL) Approach, Global Journal of Management and Business Research: C Finance, 15(11).

Outreville, J.F. (2011). The relationship between insurance growth and economic development: 80 empirical papers for a review of the literature. Working Paper, 12.

Pant, R., \& Bahadur, F. (2017). Contribution of insurance in economic growth of Nepal. JOURNAL OF ADV ANCED ACADEMIC RESEARCH (JAAR), 4(I).

Petrova, Y. (2014). The Relationship between Insurance Market Activity and Economic Growth. LUP Student Papers. 
Petrova, Y. (2019). On cointegration between the insurance market and economic activity, Empirical Economics, doi: https://doi.org/10.1007/s00181-019-01669-6

Pradhan, R.P et al. (2017). Is there a link between economic growth and insurance and banking sector activities in the G-20 countries? Review of Financial Economics, 33, 12-28.

Rakshit, D. (2017). Analysis of growth of insurance density and insurance penetration in India after initiation of reforms in insurance sector. International Journal of Research in Economics and Social Sciences (IJRESS), 7(6), 164171.

Ramoutar, R.S. (2019). The Effects of Insurances, Pensions and Mutual Funds on Economic Growth, Journal of Economics and Public Finance, 6(1), 17-27.

Skare, M., \& Porada-Rochoń, M. (2019a). Financial and economic development link in transitional economies: a spectral Granger causality analysis 1991-2017. Oeconomia Copernicana, 10(1), 7-35. https://doi.org/10.24136/oc.2019.001.

Skare, M., \& Porada-Rochoń, M. (2019b). Tracking financial cycles in ten transitional economies 2005-2018 using singular spectrum analysis (SSA) techniques. Equilibrium. Quarterly Journal of Economics and Economic Policy, 14(1), 7-29. https://doi.org/10.24136/eq.2019.001.

Sandhu, A., \& Ward, J. (2017). Future of life Insurance. Actuaries Summit. Actuaries Institute.

Satrovic, E. (2019). Meta-Analysis of the Relationship between Life Insurance and Economic Growth, Journal of Yasar University, 14, 118-125.

Sawadogo et al. (2018). Life Insurance Development and Economic Growth: Evidence from Developing Countries. JOURNAL OF ECONOMIC DEVELOPMENT, 48(2).

Scanlon, D. et al. (2007). Competition in Health Insurance Markets: Limitations of Current Measures for Policy Analysis. Medical Care Research and Review, 63(6), 37-55. doi: 10.1177/1077558706293834

Sharku, G., \& Shehu, S. (2016). Concentration of Albanian Insurance Market. Ekonomik. a management, 3.

Shirinyan, L. (2014). Financial regulation of insurance industry of Ukraine: theory and practice problems. Center for Educational Literature.

Simionescu, M. (2019). The evolution of the Romanian insurance market after 2000. Economics, Management and Sustainability, 4(1), 21-28.

Simionescu, M., Lazányi, K., Sopková, G., Dobeš, K., \& Balcerzak, A. P. (2017). Determinants of economic growth in V4 countries and Romania. Journal of Competitiveness, 9(1), 103-116.

Skuflic, L. et al. (2011). Liberalization and market concentration in the insurance industry: case of Croatia. Economic Review - Journal of Economics and Business, IX(2), 61-75.

Stojaković, A., \& Jeremić, L. (2016). Development of the insurance sector and economic growth in countries in transition. Megatrend revija Megatrend Review, 13(3), 83-106.

Sukpaiboonwat, S. et al. (2014). Measuring the Degree of Market Concentration in Thailand Insurance Industry. Asian Social Science, 10(4), 214-232.

Thalassinos, E., Cristea, M., \& Noja, G. G. (2019). Measuring active ageing within the European Union: implications on economic development. Equilibrium. Quarterly Journal of Economics and Economic Policy, 14(4), 591-609. https://doi.org/10.24136/eq.2019.028.

Todorov, A.B. (2016). Assessing Competition in the Bulgarian Insurance Industry: A Panzar-Rosse Approach. Bulgarian Economic Papers. Available from: http://www.bep.bg

Ul Din et al. (2017). Does insurance promote economic growth: A comparative study of developed and emerging/developing economies, Cogent Economics \& Finance, 5.

Ungur, C. (2017). Socio-economic valences of insurance. The Journal Contemporary Economy, 112-118.

Wang, D.S., \& Li, Y.M. (2019). The Development of Foreign Capital Insurance Market, FDI and Economic Growth in China. Modern Economy, 10, 872-885. doi: https://doi.org/10.4236/me.2019.103058

Ying, W. et al. (2017). Life insurance contribution, insurance development growth in China, The Business and Management Review, 9(1), 357-370. 